\title{
Degradation of Polycyclic Aromatic Hydrocarbons from Soil Leachate by Water Hyacinth (Eichhornia crassipes)
}

\author{
Luke N. Ukiwe ${ }^{1}$, Ubaezue U. Egereonu ${ }^{1}$, Paul C. Njoku ${ }^{1} \&$ Christopher I. A. Nwoko ${ }^{1}$ \\ ${ }^{1}$ Department of Chemistry, Federal University of Technology, Nigeria \\ Correspondence: Luke N. Ukiwe, Department of Chemistry, Federal University of Technology, P.M.B. 1526, \\ Owerri, Nigeri. Tel: 234-806-419-2946. E-mail: luggil2002@yahoo.com
}

Received: July 16, 2012 Accepted: August 9, 2012 Online Published: September 24, 2012

doi:10.5539/ijc.v4n5p55 URL: http://dx.doi.org/10.5539/ijc.v4n5p55

\begin{abstract}
The ability of water hyacinth (Eichhornia crassipes) to adsorped polycyclic aromatic hydrocarbons from contaminated soil leachate was examined. Results obtained from analysis using GC/FID indicated that naphthalene $(8.350 \mu \mathrm{g} / \mathrm{g})$ was the overall highest polycylic aromatic hydrocarbon adsorped at $\mathrm{pH} 4.0$, while pyrene $(0.057 \mu \mathrm{g} / \mathrm{g})$ was the least adsorped polycyclic aromatic hydrocarbon overall at $\mathrm{pH}$ 6.0. In ascending the $\mathrm{pH}$ from 2.0 to 6.0, there wasn't any trend observed in PAH degradation, though, it was noted that polycyclic aromatic hydrocarbons degradation increased from $\mathrm{pH} 2.0$ to 4.0 , and then, sharply decreased at $\mathrm{pH} 6.0$. This results thus lend credence to the fact that $E$. crassipes is a potential phytoremediator in removing polycyclic aromatic hydrocarbons from contaminated waste streams.
\end{abstract}

Keywords: accumulation, anthracene, contamination, petroleum, plants, pollution, uptake, rhizoremediation

\section{Introduction}

Polycyclic aromatic hydrocarbons (PAHs) are fused aromatic ring compounds that have been reported to pose great risk to the environment and human health due to their mutagenic, teratogenic and carcinogenic effects (Ukiwe, Egereonu, \& Nwoko, 2012a) and (Ukiwe \& Egereonu, 2012b). PAHs could be produced mainly from incomplete combustion of organic materials, during discharge of petroleum products or from biological transformation precursors. The efficiency of plants to adsorp PAHs from contaminated systems have been documented (Haritash \& Kaushik, 2009). Phytoremediation has become one of the most effective practical approaches used to remove PAHs from polluted substrates. Applying this approach involve two fundamental processes responsible for PAHs transfer and distribution in plants tissues. These processes include;

1) That transfer between plant tissues and cells is driven by PAHs concentration gradient across plant cell components (Providenti, Lee, \& Trevors, 1993).

2) That accumulation of PAHs in plant tissues is a function of plant lipid content (Providenti et al., 1993).

Plant uptake of PAHs from polluted media is primarily through the roots and secondarily through leaves. Adsorption from water and soil via plant roots is a major pathway of polycyclic aromatic hydrocarbon (PAH) entry into plants. Rhizoremediation is an aspect of phytoremediation involving the breakdown of contaminants in soil due to activities by microbes in the presence of the plant root zone (rhizosphere) (Gaskin, Soole, \& Bentham, 2008). Plant root exudates also help to enhance rhizoremediation by stimulating the growth of microorganism in the soil/water media which further degrade pollutants in the plant rhizosphere. Evidence abound showing that selection of plants for rhizoremediation depend on several factors namely; the general plant type, $\mathrm{pH}$, temperature, microbial population (Frick, Farrel, \& Germida, 1999; Hutchinson, Schwab, \& Banks, 2003), and variations in plant morphology and physiology (Pichtel \& Liskanen, 2001). Grasses and leguminous plants are candidate species for effective rhizoremediation (Adam \& Duncan, 2003). For a plant to qualify as candidate rhizoremediator, it must posses highly branched, fibrous root system, it must also posses the ability to grow successfully in low nutrient systems, be native to remediation site as well as be tolerant to high hydrocarbon levels (Anderson, Guthric, \& Walton, 1993). Researches have indicated that tropical grasses show special applicability to rhizoremediation most especially since they are tolerant to drought and low nutrient availability (Aprill \& Sims, 1990). 
Various plants species have been identified for their ability to enable rhizoremediation of sites contaminated with petroleum hydrocarbon (Reilley, Banks, \& Schwab, 1996). Recent studies include that of Qiu, Leland, Shah, and Sorensen (1997) and Gunther, Dornberger, and Fritsche (1996). Chen, Banks, and Schwab (2003) also suggested that tall fescue (Festuca arundinacea) and switch grass (Panicum virgatum) both could degrade about 1.6 and $8.7 \%$ pyrene in 190 days of incubation. In a related study, Chouychai et al. (2009) indicated that corn plant (Zea mays) has the ability to enhance the degradation of phenanthrene and pyrene in acidic soil inoculated with Pseudomonas putide. However, in conducting investigations into the capability of four plants species namely; $F$. arundinacea, ryegrass (Lolium perenne), alfalfa (Medicago sativa) and oil-rape seed (Brassica napus) grown alone and in combination to degrade phenanthrene and pyrene in spiked soil, Cheema et al. (2009) had noted higher degradation rates of PAHs in the combined plant cultivation ( $99 \%$ phenanthrene and $88 \%$ pyrene), compared to the single plant cultivation ( 97 and $79 \%$ of phenanthrene and pyrene), suggesting that enhanced rhizoremediation could be achieved using combined plant cultivation. As a viable clean up alternative for soils contaminated with petroleum products, Cofield, Schwab, and Banks (2007) evaluated the potential of $F$. arundinacea, P. virgatum, and zucchini (Curcubita pepo) in remediating soil from a gas plant. It was revealed that concentrations of PAHs decreased significantly in all treatments after 90 days. It has also been documented that PAHs degradation could be promoted in the rhizosphere of $F$. arundinacea with Pseudomonas fluorescens (Ho, Applegate, \& Banks, 2007). Nevertheless, using native species for rhizoremediation, plants and their associated rhizosphere microbes can enhance PAH dissipation, hence, offering an economic and ecologically attractive remediation technique (Olson et al., 2007). However, according to Nedunuri, Lowell, and Meade (2010), for rhizoremediation to be more ecologically beneficial and cost-effective, it is advisable to allow contaminated sites to re-vegetate with the native grasses.

Water hyacinth (Eichhornia crassipes) can significantly accumulate petroleum hydrocarbons from contaminated waste substrates (Ndimele, 2010). The plant posses dense highly branched, fibrous root system, it floats on water, and has been shown to tolerate low nutrient concentration (Ukiwe \& Ogukwe, 2007). E. crassipes has been tested by several researchers for its ability to adsorb aromatic hydrocarbons in effluents (Wolverton \& Mckown, 1976; O'Keeffe, Wiese, Brummet, \& Miller, 1987; Vaidyanathan, Kavadia, Rao, Basu, \& Mahajan, 1983). These studies all demonstrated that the purification performance of the effluent improved by over $89 \%$ and that the root of the plant played a critical role in the rhizoremediation process. Xia (2008) also examined the effectiveness of $E$. crassipes in removal of dicofol in contaminated waters. The study concluded that the plant was very effective in the phytoremediation process, accumulating about $50 \%$ of dicofol in 7 days demonstrating the fact that the plant may thus be a viable candidate for development as a phytoremediator for systems contaminated by organics.

The present study investigates the effectiveness of E. crassipes in adsorbing PAHs from contaminated soil leachate.

\section{Materials and Method}

\subsection{Preparation of Stock Solution}

The soil sample used in this experiment was obtained from the commercial bus park of the Federal University of Technology, Owerri, Nigeria in April, 2011, while the E. crassipes plant also used in the present experiment was harvested from Enyioha farms in Imerienwe, Ngor Okpala LGA, Nigeria, in March, 2012 and identified Dr C.E. Ihejirika, of the Department of Environmental Technology, Federal University of Technology, Owerri, Nigeria. The plant specimen number was given as; EVS 00100029. Stratification sampling method was used to select the sample site, while random sampling was then applied within each stratification sub-groups to improve representativeness of the sample. Soil pre-treatment included sieving to select particle size of $10 \mathrm{~mm}$ and air dried for $48 \mathrm{hrs}$ (Valentin et al., 2007). Obtaining this particle size was important to facilitate contact between soil and contaminant as well as organic solvent to be used for extraction.

The soil sample was autoclaved for $1 \mathrm{hr}$ at $110^{\circ} \mathrm{C}$. About $5 \mathrm{~kg}$ of the dried soil sample was placed into a $25 \mathrm{~L}$ plastic bucket previously washed and rinsed with deionized water. About $5 \mathrm{~L}$ of waste engine oil was measured and poured into the $25 \mathrm{~L}$ plastic bucket and the entire mixture was mixed thoroughly. It has been reported that waste engine oil contain appreciable amount of PAHs (Carmichael, Jacob, Grimmer, \& Phillips, 1990; Wong \& Wang, 2001). About $5 \mathrm{~L}$ of $\mathrm{n}$-hexane was further added to the triturated mixture and further trituration performed for another 10 mins. About $10 \mathrm{~L}$ of distilled water was then added to the mixture and the entire content stirred for another 10 mins and allowed to stand for 2 hrs. The supernatant was decanted and filtered through white cheese cloth and then through Whatman No. 42 filter papers. About $10 \mathrm{~L}$ of this filtrate was reserved to serve as the stock solution. 


\subsection{Preparation of E. Crassipes Samples}

The choice of E. crassipes for this experiment is based on the following desirable criteria;

1) Dense aggressive and fibrous root system for maximum surface area to trap hydrophobic contaminants (Ukiwe \& Ogukwe, 2007).

2) Dense coverage of contaminated site (Ukiwe \& Aneke, 2010).

3) High hydrocarbon tolerance (Ukiwe, Oguzie, \& Ajaero, 2008a).

4) Ability to tolerate low nutrient availability (Ukiwe, Nwoko, \& Enenebeaku, 2008b).

About four E. crassipes plants were potted in four $2 \mathrm{~L}$ plastic sample holder vessels previously washed and rinsed with distilled water. The potted plants were prepared and placed in the Project Laboratory of the Department of Chemistry, Federal University of Technology, Owerri, Nigeria. To each of three of the potted plants was added $500 \mathrm{ml}$ of distilled water and $500 \mathrm{ml}$ each of the stock solution and the mixture triturated for 5 mins and the $\mathrm{pH}$ of the mixture in the three potted plants maintained each at 2.0, 4.0,6.0, respectively using $1 \mathrm{M}$ $\mathrm{NaOH} / \mathrm{HCl}$ as appropriate. These $\mathrm{pH}$ levels were maintained for two weeks. After this period, the plants were separately harvested, cut into tiny pieces, dried and mashed separately in a porcelain mortar. The resultant substance in each of the three potted plants was separately placed in six $500 \mathrm{ml}$ beakers and $50 \mathrm{ml}$ each of nhexane solution was poured separately into the three beakers. The mixtures were separately triturated for 10 mins and filtered separately through clean cheese cloth and Whatman No. 42 filter papers into another three $500 \mathrm{ml}$ beakers. The filtrates were then concentrated to $2 \mathrm{ml}$ in a water bath at $40^{\circ} \mathrm{C}$. A Hewlett-Packard GC 6890 series 11 was used with an FID and a Hewlett-Packard HP-5 column (length, $10 \mathrm{~m}$; inner diameter (ID), $0.25 \mathrm{~mm}$; film thickness, $0.25 \mu \mathrm{m}$ ). Methylene chloride was used for column preparation. The carrier gas was helium at a pressure of $7.5 \mathrm{Ib} /$ inch and a flow rate of $2.5 \mathrm{ml} / \mathrm{min}$. The temperature program was as follows: $40^{\circ} \mathrm{C}$ for $3 \mathrm{~min}$, $40^{\circ} \mathrm{C} / \mathrm{min}$ to $300^{\circ} \mathrm{C}$, hold for $10 \mathrm{~min}$. The injector and detector temperature were 290 and $300^{\circ} \mathrm{C}$ respectively. Samples of $2 \mu \mathrm{l}$ were injected in splitless mode for $1 \mathrm{~min}$. Three replicate treatments each in each of the six beakers were processed and the mean PAHs concentration determined separately. The fourth potted plant was processed as in above without adding the stock solution. This last experiment was the control which enabled us to know if originally there were any PAHs present in the E. crassipes plant.

\subsection{Statistical Analysis}

Data is presented as arithmetic mean and standard deviation. The one-way Analysis of Variance (ANOVA) was employed to determine the difference in PAHs concentration between $\mathrm{pH}$ levels. The F-test was used to estimate significant difference in mean PAHs concentration between $\mathrm{pH}$ levels.

\section{Results}

Table 1. Values of PAHs in $\mu \mathrm{g} / \mathrm{g}$ of water hyacinth extract at various $\mathrm{pH}$ range

\begin{tabular}{ccccc}
\hline PAHs & $\mathrm{pH} 2.0^{(\mathrm{i})}$ & $\mathrm{pH} 4.0^{(\mathrm{ii})}$ & $\mathrm{pH} \mathrm{6.0}$ & Control \\
\cline { 2 - 5 } & Mean $(\mu \mathrm{g} / \mathrm{g}) \pm \mathrm{SD}$ & Mean $(\mu \mathrm{g} / \mathrm{g}) \pm \mathrm{SD}$ & Mean $(\mu \mathrm{g} / \mathrm{g}) \pm \mathrm{SD}$ & Mean $(\mu \mathrm{g} / \mathrm{g}) \pm \mathrm{SD}$ \\
\hline Naphthalene & $7.686 \pm 0.2$ & $8.350 \pm 0.1$ & $4.343 \pm 0.2$ & $\mathrm{ND}$ \\
2-methyl naphthalene & $6.384 \pm 0.1$ & $6.614 \pm 0.2$ & $4.202 \pm 0.1$ & $\mathrm{ND}$ \\
Acenaphthylene & $1.336 \pm 0.3$ & $1.416 \pm 0.1$ & $1.404 \pm 0.1$ & $\mathrm{ND}$ \\
Acenaphthrene & $1.214 \pm 0.0$ & $1.362 \pm 0.1$ & $1.326 \pm 0.1$ & $\mathrm{ND}$ \\
Fluorene & $1.126 \pm 0.1$ & $1.282 \pm 0.1$ & $1.312 \pm 0.1$ & $\mathrm{ND}$ \\
Phenanthrene & $1.215 \pm 0.1$ & $1.462 \pm 0.2$ & $1.252 \pm 0.1$ & $\mathrm{ND}$ \\
Anthracene & $1.184 \pm 0.2$ & $1.282 \pm 0.1$ & $1.388 \pm 0.2$ & $\mathrm{ND}$ \\
Fluoranthrene & $1.131 \pm 0.2$ & $1.286 \pm 0.2$ & $0.221 \pm 0.0$ & $\mathrm{ND}$ \\
Pyrene & $1.001 \pm 0.1$ & $1.105 \pm 0.0$ & $0.057 \pm 0.0$ & $\mathrm{ND}$
\end{tabular}

$F$-test $\mathrm{i}$ and ii $=1.18$; Not significantly different [standard deviation of $\mathrm{nth}(8)$ samples; $\mathrm{n}=8$ and 8 ] at $\mathrm{p}<0.05$ $\mathrm{ND}=$ Not Detected

\section{Discussion}

In the present study, two rings PAHs were mostly degraded than three ring PAHs compounds. Naphthalene $(8.350 \mu \mathrm{g} / \mathrm{g})$ was the overall highest degraded $\mathrm{PAH}$ at $\mathrm{pH} 4.0$, while pyrene $(0.057 \mu \mathrm{g} / \mathrm{g})$ was the overall least degraded PAH at $\mathrm{pH} 6.0$ (Table 1). No significant trend was observed in total PAHs degradation as $\mathrm{pH}$ was 
exceeded from $\mathrm{pH} 2.0$ to 6.0. However, an increase in PAHs degradation was observed as the $\mathrm{pH}$ was increased from 2.0 to 4.0, and reduced as the $\mathrm{pH}$ increased from 4.0 to 6.0. (Table 1). According to Nesterenko, Kirzher, Zimmels, and Armon (2012), E. crassipes devoid of rhizospheric bacteria could reduce about $45 \%$ naphthalene in waste water in 7 days. Nevertheless, the present study agrees with that claim though noting that $E$. crassipes could only reduce about $5 \%$ naphthalene within the same time frame.

Direct degradation of petroleum hydrocarbon by plants have been studied by many authors including Frick et al. (1999) and Durmishidze (1977) who examined the ability of poplar trees to assimilate n-alkanes and liberate ${ }^{14} \mathrm{CO}_{2}$. However, evidence has been accumulating on indirect degradation of hydrocarbons by plants. Gunther et al. (1996) indicated that exudates froom root of plants enable rhizosphere co-metabolic degradation of petroleum hydrocarbons. In further studies, Wolverton and Mckown (1996) showed that one hectare of the plant is potentially capable of removing about $160 \mathrm{~kg}$ of petroleum hydrocarbon from polluted water in about 4 days. Depending on the value of chemical oxygen demand (COD) of waste waters, it has been shown that E. crassipes could improve the quality of oil-refinery waste water by decreasing petroleum hydrocarbons by about $18 \%$ (Tang \& Lu, 1993). The study pointed out that when the COD of the waste water was below $131 \mathrm{mg} / \mathrm{l}$. E. crassipes degraded several hydrocarbons through adsorption and uptake of the hydrocarbon compounds leading to improved and transparent water. In an attempt to investigate the removal of phenol using E.crassipes in the presence of trace metals, Nor (1994) demonstrated that the plant has tremendous capability to adsorb phenolic compounds as well as heavy metals simultaneously. The study noted that bioassays involving filtered $E$. crassipes root extract revealed that phenol was removed by the aqueous root extract indicating involvement of cellular constituents of roots of the plant in the adsorption process. Della Greca, Previtera, and Zarrelli (2009) extensively documented evidence showing that certain structures of the PAHs compounds are involved in the ability of E. crassipes to adsorb PAHs from contaminated substrates. Two compounds identified as methyl derivatives of phenyl naphthalenedicarboxylic acid and phenyl naphthalenecarboxylic acid were linked to a phenylphenalene unit isolated from extracts of the plant. The study further suggested that given the chemistry of these compounds, the may have enabled the plant to adsorb hydrocarbons from waste streams. To the extent that certain factors (temperature, $\mathrm{pH}$, redox potential) are applied within acceptable limits, will the plant be able to adsorb petroleum hydrocarbons from waste systems. However, recent advances have suggested that the adsorption of hydrocarbons by E. crassipes is dominated by Van Der Waals forces (Lin \& Zheng, 2003), hence, the plant has capability to adsorb other compounds including inorganic nutrients and pesticides (Reddy, Agami, \& Turker, 1989; Xia \& Ma, 2006; Rosas, Carbajal, Gómez, Belmont, \& Villalobos, 1984; Ebel, Evangelou, \& Schaeffer, 2007; Ghabbour, Davies, Lam, \& Vozzella, 2004). Reddy et al. (1989), Rosas et al. (1984) and Ebel et al. (2007) all investigated the adsorption of phosphorus, potassium and cyanide by E. crassipes, while Ghabbour et al. (2004) noted that the presence of humic acids in the leaves, stem and root of the plant is related to the binding properties of these acids, while Xia and Ma (2006) also examined the ability of the plant to adsorb organo-pesticides and concluded that E. crassipes has the ability to adsorp about $81 \%$ of ethion in one week using its roots.

Despite these recognized studies, the present study however notes that studies relating to PAHs adsorption by $E$. crassipes are rare.

\section{Conclusion}

Phytoremediation using E. crassipes was performed in degrading PAHs from contaminated soil leachate. Naphthalene and 2-methylnaphthalene were highly degraded by the plant, while pyrene and fluoranthrene were least degraded, showing that $E$. crassipes is effective as candidate plant in removing PAHs from contaminated streams. The present study thus agree with a growing body of literature beginning to accumulate over the years that two rings PAHs are easily degraded by plants species than three and above ring PAHs.

\section{Acknowledgement}

We thank Dr. C. E. Ihejirika of the Department of Environmental Technology, Federal University of Technology, Owerri, Nigeria, for his invaluable contributions.

\section{References}

Adam, G., \& Duncan, H. (2002). Influence of diesel fuel on seed germination. Environmental Pollution, 120, 363-370. http://dx.doi.org/10.1016/S0269-7491(04)00119-7

Anderson, T., Guthric, E., \& Walton, B. (1993). Bioremediation in the rhizosphere. Environmental Science and Technology, 27, 2630-2636. http://dx.doi.org/10.1021/es000499001 
Aprill, W., \& Sims, R. (1990). Evaluation of the use of prairie grasses for stimulating polycyclic aromatic hydrocarbon treatment in soil. Chemosphere, 20, 253-265.

Carmichael, P. L., Jacob, J., Grimmer, G., \& Phillips, D. H. (1990). Analysis of polycyclic aromatic hydrocarbon content of petrol and diesel engine lubricating oils and determination of DNA adducts in tropically treated mice by ${ }^{32}$ P-postlabelling. Carcinogenesis, 11, 2025-2032. http://dx.doi.org/10.1093/carcin/11.11.2025

Cheema, S. A., Khan, M. I., Shen, C., Tang, X., Farooq, M., Chen, L., ... Chen, Y. (2009). Degradation of phenanthrene and pyrene in spiked soils by single and combined plants cultivation. Journal of Hazardous Materials, 30, 996-1004. http://dx.doi.org/10.1016/j.jhazmat.2009.12.044

Chen, Y. C., Banks, M. K., \& Schwab, A. P. (2003). Pyrene degradation in the rhizosphere of tall fescue (Festuca arundinacea) and switchgrass (Panicum virgatum). Environmental Science and Technology, 37, 5778-5782. http://dx.doi.org/10.1021/es030400x

Chouychai, W., Thongkukiatkul, A., Upatham, S., Lee, H., Pokethitiyook, P., \& Kruatrachuc, M. (2009). Plant enhanced phenanthrene and pyrene biodegradation in acidic soil. Journal of Environmental Biology, 30, 139-144.

Cofield, N., Schwab, A. P., \& Banks, M. K. (2007). Phytoremediation of polycyclic aromatic hydrocarbons in soils: Part 1, Dissipation of target contaminants. International Journal of Phytoremediation, 9, 355-370. http://dx.doi.org/10.1080/15226510701603858

DellaGreca, M., Previtera, L., \& Zarrelli, A. (2009). Structures of new phenylphenalene related compounds from Eichhornia crassipes (Water hyacinth). Tetrahedron, 65, 8206-8208. http://dx.doi.org/10.1016/j.tet.2009.07.069

Durmishidze, S. V. (1977). Metabolism of certain air polluting organic compounds in plants. Prikladnaia Biohimiial Mikrobiologiia, 13, 646-653.

Ebel, M., Evangelou, M. W. H., \& Schaeffer, A. (2007). Cyanide phytoremediation by water hyacinths (Eichhornia crassipes). Chemosphere, 66, 816-823. http://dx.doi.org/10.1016/j.chemosphere.2006.06.041

Frick, C., Farrel, R., \& Germida, J. (1999). Assessment of phytoremediation as an in-situ technique for cleaning oil-contamination site. Retrieved from www.clu-in.info/phyassess

Gaskin, S., Soole, K., \& Bentham, R. (2008). Screening of Australian native grasse for rhizoremediation of aliphatic hydrocarbon contaminated soil. International Journal of Phytoremediation, 10, 375-389. http://dx.doi.org/10.1080/152265/0802100465

Ghabbour, E. A., Davies, G., Lam, Y. Y., \& Vozzella, M. E. (2004). Metal binding by humic acids isolated from water hyacinth plants (Eichhornia crassipes; solm-laubach: Pontedericeae) in the Nile Delta, Egypt. Environmental Pollution, 131, 445-451. http://dx.doi.org/10.1016/j.chemosphere.2005.08.049

Gunther, T., Dornberger, U., \& Fritsche, W. (1996). Effects of ryegrass on biodegradation of hydrocarbons in soil. Chemosphere, 33, 203-216. http://dx.doi.org/10.1016/0045-6535(96)00164-6

Haritash, A. K., \& Kaushik, C. P. (2009). Biodegradation aspects of polycyclic aromatic hydrocarbons (PAHs): A review. Journal of Hazardous Materials, 169, 1-15. http://dx.doi.org/10.1016/j.jhazmat.2009.03.137

Ho, C. H., Applegate, B., \& Banks, M. K. (2007). Impact of microbial/plant interactions on the transformation of polycyclic aromatic hydrocarbons in rhizosphere of Festuca arundinacea. International Journal of Phytoremediation, 9, 107-114. http://dx.doi.org/10.1080/15226510701232765

Hutchinson, S., Schwab, A., \& Banks, M. (2003). Phytoremediation: Transformation and Control of Contaminants (1st ed.). New York: John Wiley, 355-386.

Lin, Z. X., \& Zheng, F. X. (2003). Study on adsorption process for nitrobenzene on water hyacinth root. Shanghai Environmental Sciences, 12, 703-709. http://dx.doi.org/10.1021/ie0308487

Ndimele, P. E. (2010). A review on the phytoremediation of petroleum hydrocarbons. Pakistan Journal of Biological Sciences, 13, 715-722. http://dx.doi.org/10.3923/pjbs.2010.715.722

Nedunuri, K. V., Lowell, C., Meade, W., Vonderheide, A. P., \& Shann, J. R. (2010). Management practices and phytoremediation by native grasses. International Journal of Phytoremediation, 12, 200-214. http://dx.doi.org/10.1080/1522651090323928 
Nesterenko, M. A., Kirzhner, F., Zimmels, Y., \& Armon, R. (2012). Eichhornia crassipes capability to remove naphthalene from waste water in the absence of bacteria. Chemosphere, 87, 1186-1191. http://dx.doi.org/10.1016/j.chemosphere.2012.01.060

Nor, Y. M. (1994). Phenol removal by Eichhornia crassipes in the presence of trace metals. Water Research, 28, 1161-1166.

O'Keeffe, D., Wiese T., Brummet, S., \& Miller, T. (1987). Uptake and metabolism of phenolic compounds by the water hyacinth (Eichhornia crassipes). Recent Advances in Phytochemistry, 21, 101-121.

Olson, P. E., Castro, A., Joern, M., Duteau, N. M., Pilon-Smits, E. A. H., \& Reardon, K. F. (2007). Comparison of plant families in a greenhouse phytoremediation study on an aged polycyclic aromatic hydrocarbon contaminated soil. Journal of Environmental Quality, 36, 1461-1469.

Pichtel, J., \& Liskanen, P. (2001). Degradation of diesel fuel in rhizosphere soil. Environmental Engineering and Science, $18,145-157$.

Providenti, M. A., Lee, H., \& Trevors, J. T. (1993). Selected factors limiting the microbial degradation of recalcitrant compounds. Journal of Industrial Microbiology, 12, 379-395. http://dx.doi.org/10.1007/BF01569669

Qiu, X., Leland, T. W., Shah, S. I., Sorensen, D. L., \& Kendall, E. W. (1997). Field study: Grass remediation for clay soil contaminated with polycyclic aromatic hydrocarbons. In: Phytoremediation of Soil and Water Contaminants. Kruger, E. L., Anderson, T. A., Coates, J. R. (Eds). Washington DC: American Chemical Society, 186-199. http://dx.doi.org/10.1021/bk-1997-0664.ch014

Reddy, K. R., Agami, M., \& Tucker, J. C. (1989). Influence of nitrogen supply rates on growth and nutrient storage by water hyacinth (Eichhornia crassipes) plants. Aquatic Botany, 36, 33-43. http://dx.doi.org/10.1016/0304-3770(89)90089-2

Reilley, K. A., Banks, M. K., \& Schwab, A. P. (1996). Organic chemicals in the environment: Dissipation of polycyclic aromatic hydrocarbons in the rhizosphere. Journal of Environmental Quality, 25, 212-219.

Rosas, I., Carbajal, M. E., Gómez, A. S., Belmont, R., \& Villalobos, P. R. (1984). Cytogenetic effects of cadmium accumulation on water hyacinth (Eichhornia crassipes). Environmental Research, 33, 386-395. http://dx.doi.org/10.1016/0013-9351(84)90037-9

Tang, S. Y., \& Lu, X. W. (1993). The use of Eichhornia crassipes to cleanse oil-refinery wastewater in China. Ecological Engineering, 2, 243-251. http://dx.doi.org/10.1016/0925-8574(93)90017-A

Ukiwe, L. N., \& Aneke J. N. (2010). Hyperaccumulation: An aspect of EDTA chelate-assisted phytoextraction by water hyacinth. The African Journal of Plant Science and Biotechnology, 4, 107-110.

Ukiwe, L. N., \& Egereonu, U. U. (2012b). PH and sulphate mass: Intensity factors in investigating sulphatedependent degradation of polycyclic aromatic hydrocarbons. Advances in Applied Science Research, 3, 1132-1136.

Ukiwe, L. N., \& Ogukwe, C. E. (2007). Potassium ion uptake by water hyacinth (Eichhornia crassipes) on the lower reaches of the Niger River, Nigeria. The African Journal of plant Science and Biotechnology, 1, 3639.

Ukiwe, L. N., Egereonu, U. U., \& Nwoko, C. I. A. (2012a). Effect of pH in evaluating phosphate-dependent degradation of polycyclic aromatic hydrocarbons in contaminated soil leachate. Der Chemica Sinica, 3, 373-377.

Ukiwe, L. N., Nwoko, C. I. A., \& Enenebeaku, C. K. (2008b). Intrinsic role of pH variables on the sorption of heavy metals by Water hyacinth (Eichhornia crassipes) on the Niger Delta rivers, Nigeria. The African Journal of Plant Science and Biotechnology, 2, 112-114.

Ukiwe, L. N., Oguzie, E. E., \& Ajaero, C. (2008a). Adsorptive property, ash content analysis of activated carbon derived from three Nigerian Plants: Water hyacinth (Eichhornia crassipes), Iroko (Chloraphora excelsa), and Gmelina (Gmelina arborea). The African Journal of Plant Science and Biotechnology, 2, 109-111.

Vaidyanathan, S., Kavadia, K., Rao, M., Basu, S., \& Mahajan, S. (1983). Removal of phenol using water hyacinth in a continous unit. International Journal of Environmental Studies, 21, 181-191. http://dx.doi.org/10.1080/00207238308710075 
Valentin, I., Lu-Chau, T. A., Lópex, C., Feijoo, G., Moreira, M. T., \& Lema, J. M. (2007). Biodegradation of dibenzothiophene, fluoranthene, pyrene and chrysene in soil slurry reactor by the white-rot fungus Bjerkandera sp. Process Biochemistry, 42, 641-648. http://dx.doi.org/10.1016/j.procbio.2006.11.011

Wolverton, B., \& Mckown, M. (1976). Water hyacinth for removal of phenols from polluted waters. Aquatic Botany, 2, 191-202. http://dx.doi.org/101016/0304-3770(76)90020-6

Wong, P. K., \& Wang, J. (2001). The accumulation of polycyclic aromatic hydrocarbons in lubricating oil overtime-a comparison of supercritical fluid and liquid-liquid extraction methods. Environmental Pollution, 112, 407-415. http://dx.doi.org/10.1016/S0269-7491(00)00142-1

Xia, H. (2008). Enhanced disappearance of dicofol by water hyacinth in water. Environmental Technology, 29, 297-302. http://dx.doi.org/10.1080/0959330802099684

Xia, H., \& Ma, X. (2006). Phytoremediation of ethion by water hyacinth (Eichhornia crassipes) from water. Bioresource Technology, 97, 1050-1054. http://dx.doi.org/10.1016/j.biortech.2005.04.039 